\title{
THE SOCIAL POSITION OF WOMEN IN GHANA ${ }^{1}$
}

\author{
By Agnes Klingshirn
}

In order to be able to judge the comparative status of women in Ghana and show the extent of the changes that have taken plane in recent years, I shall briefly summarize their position in traditional society. A survey demonstrated, that the woman had a secure, clearly defined place in the system of traditional social relationships, with unequivocal rights and obligations, a position which provided her with a reliable social orientation. At the same time, however, it became evident that in this traditional system the basic inequality of the women was a self-evident presupposition, which was not questioned and which, therefore, could not become a problem in the traditional social context. From the point of view of a changed socio-cultural world, however, the various dependencies, subjugations, and inequalities to which the woman in traditional society was, and partly still is, subjected, become evident.

\section{The woman in the traditional family life}

With some exceptions (primarily the Akim and Ga women farmers and more recently the full-time traders in the urban centers) the Ghanaian woman had a claim to proper care vis-à-vis her parents, her husband and in old age her children, but was economically dependent in all these primary relationships. Until her husband can build a house of his own - which often is not until she has borne several children - the house of her father is in many cases long afterwards still her only place of residence; this applies also to old age or to the case where a husband divorces his wife.

The underprivileged position of the woman becomes especially apparent in the traditional marriage. Not only was this the only acceptable state for the woman to be in ${ }^{2}$, but rather than individual happiness the main reason for marriage was the procreation of children. Marriages were traditionally arranged by the two families concerned, whereby personal preferences ranged behind lineage-political matters. In order to strengthen the family ties - in emotional as well as economical respects (i. e. preserving property) - cross-cousin marriages were common. That this type of marriage is regressing, is the result of social changes: a growing mobility, caused by the necessity to find work, the lack of fixed property, and changing inheritance patterns, which result in a dysfunctionality of the old customs ${ }^{3}$.

\footnotetext{
1 This article contains primarily the results of my doctoral thesis, presented to the Faculty of Arts at the Marburg (W. Germany) University in May 1971 and available only in mimeographed form. This was an empirical study based on material gathered in detailed guided interviews of a random sample of 58 cases and personal observations in Larteh, a small town in Southern Ghana, over a period of eight months from October 1965 to May 1966, substantiated by intermittent previous field experience spaced over one and a half years from 1962-1964. In addition use was made of available statistical material, such as the 1960 Census and comparative literature.

2 In the 1960 Post Enumeration Survey $91 \%$ of all women aged 15 and above were either married, divorced or widowed. Cf. P. Austin Tetteh, "Marriage, Family and Household", in: W. Birmingham a. o. (Eds.), A Study of Contemporary Ghana, Vol. 2, London, 1967, p. 201.

3 But even where young, educated people today tend to put love first and to choose their own partners, they are still heavily dependent on family approval and have introverted traditional norms, so that a record of family health and high fertility are still the two most important family factors in the selection of a mate. Cf. Harold Feldman, The Ghanaian Family in Transition, Legon, no date, (about 1962), mimeographed, pp. $51-55$.
} 
A woman's dependence on her husband is determined by "patriarchalism": he provides for the material well-being of his wife and children while she is responssible for the housekeeping, the food production and the rearing of the small children. All relevant decisions are taken by the husband: he controls the finances, is responsible for the education of the children and represents the family to the outside. The man has the exclusive right to dispose of fixed property as well as of the income from the labor expended on the farm. The woman, however, is excluded from the possibility of acquiring economically relevant property - aside from the sale of surplus food products and small scale trading.

In the traditional agrarian society the institution of polygamy provided the man with extra unpaid labor and the study showed that the endeavor to have as many women and children as possible as cheap laborers is the economic core of polygamy. Despite the fact that polygamy was traditionally aspired to by most men, however, the fact that the sex ratio is nearly equal resulted in the majority of men being monogamous at least during the greater part of their lives ${ }^{4}$.

The patterns of inheritance, likewise, are oriented towards the man. Property and political office pass either directly from father to son or, among the matrilineal Akan, to mother's brother or sister's son.

The traditional divorce law also placed the woman at a disadvantage. The relative facility in obtaining a divorce favored the man, because he had greater economic securities and better opportunities to marry again ${ }^{5}$. The situation was especially aggravating for the woman when divorce occurred when she was past the childbearing age. The husband would marry a younger wife then, but she would be left without someone to care for her ${ }^{6}$.

The social discrimination finds another expression in the sexual suppression of the woman. Pregnancy before the completion of the puberty ceremony was heavily penalized, including banishment or even death, and in some societies the young girls had to submit to chastity ordeals. With few exceptions (such as the Krobo, for instance), there was virtually no sexual enlightenment, pregnancy prevention measures were unknown and undesirable and abortion was practiced only when the life of the woman was in danger (that is, when it was suspected that she had committed adultery during pregnancy).

The married woman is allowed sexual relations only with her husband, while the husband is allowed all sexual liberties. He can satisfy his libidinal desires on the one hand through the institution of polygamy, and on the other in extra-marital relationships, whereby only cohabitation with another married, not with a single woman, is taken as adultery and may be penalized. The sexuality of the woman is limited to the function of bearing children; she is socially recognized only as

4 Today polygamy is regressing. The reduction is more significant in the cities than in the rural areas and is primarily the result of a changed economic situation - children's education, rising costs of living, housing shortage - and only secondly of the influence of Christian teachings and modern education.

5 The commonest reason for divorce was the man's negligence to maintain his wife. Other causes included childlessness or bearing only daughters, unfaithfulness (on the part of the woman), physical cruelty or polygamy (when the wife did not agree to have a co-wife in the house).

6 This is the reason why today more women than men prefer a church or civil wedding, which, in contrast to the traditional marriage, render divorce more difficult. This concerns primarily the educated, however, for the 1960 Post Enumeration Survey showed that the majority of Ghanaians $(86 \%)$. were still married under traditional law. Among training college students, on the other hand, approximately $50 \%$ preferred either a church or civil or a combined church and civil marriage. Among my sample there were twice as many woman than men. Among university students the preference for these latter types of marriages amounted to $75 \%$ among the men and as high as $95 \%$ among the women. Cf. Feldman, p. 14 and T. Peter Omari, "Changing Attitudes of Students in West African Society Towards Marriage and Family Relationships", in: The British Journal of Sociology, Vol. 11, London 1960, p. 201. 
mother. In traditional society it is much more difficult for the woman to realize her desire for sexual pleasure and individual happiness than it is for the man?

A woman's almost exclusive limitation to the home area - caring for the children, house - and fieldwork - also does not give her an opportunity to become active in public life. The only exception was the queenmother, the female counterpart of the chief. Her office was most fully developed among the matrilineal Akan ${ }^{8}$.

That the woman is placed at a disadvantage compared to the man finally becomes apparent in old age. As already stated, at this time the husband of ten divorces his wife, so that he does not have to care for her and can take a younger one, or he simply lives separated from her, so that old women generally are not found to be living with their husbands ${ }^{9}$. For the man, who is in the possession of property and possibly of a young wife, old age is much less of a problem. Nevertheless, even for a woman this used to be a time she could look forward to, for, surrounded by her children and grandchildren, she occupied a central place of honor, and also made an important contribution in helping to bring up the grandchildren ${ }^{\mathbf{1 0}}$.

\section{The woman in transition to "modern" society}

The position of the woman is in all areas in a state of radical change. Everywhere, where the agrarian-rural conditions are displaced by the beginning industrialization and the urbanization connected with it, the traditional social norms are disintegrating. The small family replaces the extended family - and everything connected with it -, which becomes dysfunctional in the city. Limitations for the woman are increasingly disappearing: she may possess fixed property, is permitted to hold public offices, can choose her own marriage partner, is receiving a better education and, therefore, has better work opportunities. Polygamy gives way to monogamy with a changed marriage and divorce law, which offers greater security to the woman.

The factors which are of decisive importance for the changing position of women are:

7 All these inequalities, however, disappear in the same measure as the women are becoming more economically independent, are less under the control of the extended family when they live in the city, and become increasingly educated. The strongest attacks on the traditional type of marriage come from the educated girls and women.

8 The queenmother was primarily responsible for matters pertaining to the women (i. e. puberty rites for girls), supervised the socialization of the young - assuring that they were brought up in accordance with ancestral traditions, watched over the correct transmission and performance of the ancestral customs, had an important function in the election of a new chief, and took the place ancestral customs, had an important function in the election of a new chief, and took the place
of the chief at home in case of war. Among the patrilineal tribes, however, she had only a relatively unimportant, largely representational function. See also K. A. Busia, The Position of the Chief in the Modern Political System of Ashanti, London, 1951 and J. K. Opoku-Ampomah, "Introducing an Ashanti Girl into Womanhood", in: Ghana Notes and Queries, No. 2, Achimota, 1961.

9 Among the Gonja of Northern Ghana, for instance, E. Goody found that almost all women aged fifty and over among the ruling class and the Moslems and $69 \%$ of the commoners had separated from their husbands. She considered this to "represent a final and permanent identification of a woman with her kin. . ." E. N. Goody, "Conjugal Separation and Divorce among the Gonja of Northern Ghana." In: M. Fortes (Ed.), Marriage in Tribal Societies. Cambridge Papers in Social Anthropology No. 3, Cambridge 1962, pp. 37 and 48. - In one case in my survey, for instance, a man had divorced eight of his ten wives in the course of time. In another case a man merely lived separated from four of his six wives when they were too old to have children. Of these 12 women only 3 had remarried. The others were partly depending on their children for support, partly they were caring for themselves thro:ıch sinall-scale trading.

10 Traditionally it is the almost sacred duty of the children to care for their old parents, and this ren ally is still the case. $80 \%$ of the old women in the sample, for instance, received assistance from their children. However, the changes in other areas also have their effects on the position of old people, especially old women. Where the children have moved to the towns they sometimes fail to look after their ageing parents, particularly where, as a result of modern circumstances, these have lost their function in the socialisation of the young. This indicates that in the future old people are likely to depend increasingly on social welfare and national old age insurance. 
(1) Socio-economic changes brought about by the introduction of a money economy, industrialization and urbanization.

(2) Connected with this, modern education, which provides the necessary qualifications for the new socio-economic requirements and adjusts behavioural norms and expectations to it.

(3) A significant role as factor of innovation in favor of the women through the introduction of Western social conditions was played, in the past, by Christianity.

(4) Of great importance were also the policies of the independent Ghanaian government ${ }^{11}$.

We shall now examine the changes that have taken place in recent times in the most important social areas - economic life, education, public, and religious life. We shall see that although substantial changes have occurred, economic dependence and traditional prejudices prevent the women from achieving a fully emancipated position.

\section{Economic life}

According to occupational statistics Ghana is still strongly oriented towards agriculture: $57 \%$ of the male and $58 \%$ of the total female labor force are working in this sector ${ }^{12}$. It turned out, however, that the most lucrative sources of income in this area, cocoa-farming and palm-oil production, are predominantly in the hands of men. Approximately $43 \%$ of all males employed in agriculture are found in these two sectors, but only $27 \%$ of the women. Even then the women own the land only in exceptional cases. Their economic role, on the contrary, is that of dependent laborers on their husbands' or fathers' farms ${ }^{\mathbf{1 3}}$.

The women are primarily occupied with producing the necessary foodstuffs for the family and are largely excluded from cash crop farming. Although a woman may keep the income from the sale of surplus foodstuffs for her own use and, if she has land from her own lineage for use, she may grow some cash crops there, but since most of her time is taken up with work for her husband and care for the household, this usually does not amount to much. To a certain degree a woman is forced to try to have some income of her own, because, for one, she cannot expect her husband to pay for any extra wishes and desires she may have, secondly, she has to see to it, that she has some reserve funds for her old age, when it may well be that her husband will leave her, and thirdly, she wants her own children to profit from it.

As men are more and more occupied in industry and the prerequisite for advancement and social prestige becomes, instead, a qualified education, agriculture loses its importance and women are increasingly permitted to become land-owners. Despite this, farming as a full-time occupation is losing in importance even for the women. In the Larteh sample, where farming still occupied $75 \%$ of the mothers of the interviewees, this amounted to only $33 \%$ of the women in the sample itself, while among the interviewees' daughters only approximately $15 \%$ were, or expected to be occupied in farming.

\footnotetext{
11 Whenever I speak of the Ghanaian government, this covers primarily the period from independence to the fall of the Nkrumah regime.

121960 Population Census, Vol. IV, Table 3, p. 17. Accra, 1964.

13 An exception are the Akim women farmers and the Ga women, who may inherit land and trees from
} their mothers. 
Instead, where a woman has the chance, she prefers to trade. Next to agriculture, the highest number of the total female labour force $(27 \%)$ is engaged in trading ${ }^{14}$. But just as in agriculture the men were in control of the cash crops, so in the trade sector big business trading is almost entirely in the hands of men (with the exception of food-wholesaling). Although the proportion of men in the entire trading business amounts to only approximately $35 \%$, in the wholesale sector this rises to nearly $98 \% 0^{15}$. In small-scale trading, however, the men's interest has decreased in the same measure as they stepped into the betterpaid positions of the European-determined economic and government sectors.

For the women, on the other hand - though the profits earned in petty trading are small (in Larteh the average was between $\$ 4$ and $\$ 5$ a month) - trading offers an opportunity, even for the illiterate woman, to become more independent and it provides them with a basis for adjusting to an emancipated status.

\section{Education}

From the beginning the missions had proclaimed the importance of female education. As a result, as early as 1918, the ratio of boys to girls in all Basel mission schools was 2.7 to 1 , while it was still 6 to 1 in government schools. The educational perspective of the missions, however, was primarily to train the girls to be good Christian housewives and mothers.

Despite the efforts of the missions and later also of the Ghanaian government, however, up till the present there is a discrepancy between the literacy level of males and females ${ }^{16}$. According to the 1960 Census $29 \%$ of the males and only $11 \%$ of the females were literate. The reasons for this discrepancy are - aside from negative attitudes to female education in general - primarily of an economic nature. The school attendance of the children brings about additional costs and the parents are more easily prepared to carry such costs where a boy is concerned, because they expect later to profit from his education. A daughter, on the other hand, was expected to marry and not to make any practical use of her training. Another factor was that when children went to school they were lost as cheap working power on the farm or in the home.

As it became apparent that educated girls are able to apply their knowledge in practice, of ten even after marriage, traditional attitudes and prejudices changed. Furthermore, educated men increasingly prefer to marry educated women and in addition to the higher bride-wealth, which the parents receive when their daughter is educated, they also become a factor of prestige for them.

Although educational facilities at the lower levels are now increasingly available to the girls the same as to the boys, it must still be admitted, that the percentage of girls decreases rapidly the higher the level of education. In 1965, for example, when the percentage of girls to boys was about equal at the primary level, it amounted to only about $25 \%$ at the secondary school level, and it was a s low as $10 \%$ at the university ${ }^{17}$.

As far as the occupational opportunities for girls based on education are concerned, there are three types of professions, in which a remarkable increase in the propor-

14 There are enormous regional variations, ranging from $8 \%$ in the rural North to $70 \%$ in the capital city. 1960 Population Census, Vol. IV, Table 3, p. 21.

15 Ibid.

16 For a more general treatment of the subject of education see: Philip Foster, Education and Social Change in Ghana, London, 1965; John Wilson, Education and Changing West African Culture, New York, 1963; C. B. Wise, A History of Education in British West Africa, London, 1956, and others.

17 Sunday Mirror, March 27, 1966. 
tion of women is noticeable, especially in the lower age categories. This is the case (1) among teachers: in the 1960 Census the ratio of female to male teachers was 0.28 , but $54 \%$ of the females and only $41 \%$ of the males were in the youngest age group; (2) among nurses: here the ratio was 0.95 , and again nearly $54 \%$ of the females, but this time only $22 \%$ of the males were in the youngest age group; among the nurses under training there were three times as many women as men; (3) in clerical employment: although the number of women occupied in this profession amounts as yet only to about $8 \%$, the significance lies again in the fact, that $53 \%$ of them were in the youngest age group, while this amounted to only $30 \%$ among the men ${ }^{18}$.

However, an important reservation must be made: although the proportion of females in the teaching profession is growing rapidly, this increase is concentrated at the primary and middle school level. But - as indicated by enquiries - teaching at this level is not very attractive in either prestige or income, so that an increase in female employment here does not enhance the status of women significantly. If we consider the expansion of female employment in the nursing sector, we find a similar situation. - The increase of women in these professions, therefore, can be explained with the fact, that there is no significant competition from men for these jobs.

\section{Public life}

As has been noted, except for the queenmother, women did not participate actively in the political life of the traditional society. The British colonial government also made no efforts to encourage women to participate in political activities. This was changed only with the modern, African-dominated government, which was the first (in 1954) to grant the women the same political rights as the men. The women advanced a good deal on their way to an emancipated status through the important contribution, which they made to the struggle for independence, for up till then politics was almost exclusively men's business ${ }^{19}$. The first independent Ghanaian government expended great efforts - through comprehensive political education programs for the mostly illiterate masses of women throughout the country - to translate the equality of rights, existing theoretically, into the everyday reality of the women, which is essential for a realization of these rights. This program was carried out with the technical assistance of mass media, the personal contacts of female political leaders, or through the organization of women in political parties or other associations, in which they could gain experience at the local and national levels of political activity.

Of course, the success of these efforts is limited. Now as before, the attitude of a large proportion of the men is negative as regards the participation of women in politics. And the attitude of the women themselves is, to a large extent, also determined by the respective behavior of the men towards them, and they are, therefore, largely politically disinterested. Certainly, they are able to defend their economic interests with energy, but generally they do not draw the connection

\footnotetext{
181960 Population Census, Vol. IV, Table 12, pp. 130-131.

19 In his autobiography Nkrumah gave recognition to the valuable assistance received from the women of Ghana in their joint struggle for independence, when he writes: "Much of the success of the Convention People's Party has been due to the efforts of women members. From the very beginning women have been the chief field organisers. They have travelled through innumerable towns and villages in the role of propaganda secretaries and have been responsible for the most part in bringing about the solidarity and cohesion of the Party." Kwame Nkrumah, The Autobiography of Kwame Nkrumah, Edinburgh $1961^{3}$, p. 89. See also Richard Wright, Black Power, New York, 1954 , p. 103.
} 
between economics and politics. The only criterion of judgement was whether the women were personally affected by a specific matter or not (i. e. if there was no electricity in Larteh, the importance of the Volta dam for the country could not be assessed $)^{20}$.

An important role in the exercise of defending the interests of women in public, and with this in their emancipation, was played by various types of voluntary organization ${ }^{21}$. As a result of the extensive insecurity caused by the rapid social change, especially as far as the break-down of many of the functions of the extended family is concerned, these organizations arose as a kind of self-help institution, as a substitute for a comprehensive social security system at the national level, and as an attempt on the part of the women to achieve greater economic independence ${ }^{22}$. The fact, that in certain organizations, namely the mutual aid or benevolent thrift societies, the women predominate almost 10 to 1 , is a visible sign of their greater economic and social insecurity. The most important of these organizations, which, to some extent, have a political significance, are the trade associations in the larger cities. Here, among the organized market women, who actively supported the struggle for independence with boycotts and strikes, sooner than anywhere else, the defense of their own economic interests will lead to the realization that political decisions may have a direct influence on other areas of life ${ }^{23}$.

\section{Religious life}

A noticeable change in the situation of the women occurred through Christianity. It brought more improvements in the position of the women than of the men, which may be one reason, why the churches were supported more actively by the women; in Larteh the ratio between male and female church membership is 1 to 2 . At all levels efforts were made by the Christian churches to further the ideal of equality between men and women. They promoted the education of girls, worked out new inheritance arrangements, which offered greater security to the widows ${ }^{24}$, and encouraged changes in the marriage and divorce laws in favor of the women; on the social level membership in church organizations has opened up new avenues of gaining prestige and an opportunity for education on an informal level ${ }^{25}$. These religious women's organizations also played an important part in the translation of the new norms, brought about by Christianity, into the everyday reality of the women and in the practice of a way of life in accordance with these new norms; they function as an orientational guide for the women in problems of daily living.

20 For a more general discussion on political power and economic interests in Ghana, see Max Owusu, Uses and Abuses of Political Power, Chicago, 1970.

21 Such voluntary organizations may be based on common economic interests (i. e. fishmongers association), tribal affiliation or common locality (i. e. Larteh youth association), church membership (i. e. Methodist women's fellowship), or on a general interest in the welfare of the society (i. e. Ghana Society for the Blind).

22 For a detailed analysis of these modern associations see: K. Little, West African Urbanization. A study of voluntary associations in social change. London 1965; J. S. Coleman, The Role of Tribal Associations in Nigeria, Ibadan, 1952; also M. L. Clarkson, Report on Enquiry with Regard to Friendly and Mutual Benefit Groups in the Gold Coast 1954, Accra, 1955.

23 The Accra Market Traders Association, for instance, listed as point 10 of the aims of the association: "To promote, support, or oppose any legislative or ohter measures affecting the interest of market traders." I. Acquah, Accra Survey, London, 1958, p. 86.

24 Whereas customary law held that a relative inherited all the deceased's property, along with the obligation to care for the widow and children, it has now become popular, under Christian influence, for the widow to inherit one third of the estate, the children one third, and the customary inheritor one third.

25 Each church has at least one, many several women's organizations. There are women's fellowship groups, choirs, singing bands, youth guilds. During Sunday services and on other special occasions in which the group as a whole participates, the various groups wear a unified form of dress to distinguish them as members of a certain organization. 
That in this process of innovation religion cannot be separated from the other social areas, but that it rather - almost as a stopgap for social institutions, which are still lacking - takes over certain other functions, this is shown by the syncretistic movements, which have sprung up all over the country ${ }^{26}$. They may be understood, one the one hand, as a reaction of the men against the innovations as they concern the new position of women ${ }^{27}$, but also as an adaptation of the imported Western forms and ideas to the requirements of the Africans. In certain respects they take over functions for their members, which were hitherto carried out by the old kinship system, and for which, so far, no satisfactory substitute has been offered 28 .

Another key phenomenon, on which the conflict resulting from the social upheaval can be demonstrated, is witchcraft ${ }^{29}$. Wherever unexpected difficulties, frustrations, or unsolved conflicts appear, those concerned tend to ascribe this to the actions of witches. In accordance with typical sociopsychologic patterns, the inexplicable causes of the conflicts are personalized, here in the form of witches, and projected into suitable, that is, usually socially not fully integrated persons within the immediate (family, lineage) or more remote (work colleagues) reference group, in order to be able to persecute the personalized causes of the conflicts in the shape of witches. That the witches are generally women, results from their socially weaker position, which makes them potentially disintegrated - we only need to recall the situation of the ageing wife, who is pushed out of her position by a younger woman, or the woman, who has no economic security in old age, or is completely dependent on her children ${ }^{30}$.

The enormous increase of the witchcraft phenomenon in the last decades shows, that the social problem hidden behind this religious form is not limited to the traditional society. The insecurity resulting from the rapid social and economic turnover creates new conflicts, whose solution is attempted in the old, irrational way by means of religious prejudices and scapegoat mechanisms.

\section{Conclusions}

Summarizing, it may be said that although in traditional society a woman had clearly defined rights and duties, her economic dependence practically kept her a minor. The changes that are taking place in the various areas of social life allow for the gradual attainment of a more emancipated status, but at the same time new problems appear and there are greater orientational insecurities in the period of transition.

26 This subject has been treated in detail by C. G. Baeta, Prophetism in Ghana: A Study of Some 'Spiritual' Churches, London, 1962; G. Parrinder, Religion in an African City, London, 1953; K. Schlosser, Propheten in Afrika, Kulturgeschichtliche Forschungen, Band 3, Braunschweig, 1949; B. Sundkler, Bantu Prophets in South Africa, London, $1961^{2}$, and others.

27 Many of these churches issue strict regulations concerning female members, which have as their objective the repression of equality between men and women in public. Thus Baeta (p. 63) notes, that one such church advertises "the teaching of women novices of unquestioning obedience and humility towards the men set over them."

28 A feeling of group solidarity is emphasized and members are encouraged to cooperate with one

29 For further details see: H. W. Debrunner, Witchcraft in Ghana, Zürich, 1959; M. J. Field, Search for Security. An Ethno-Psychiatric Study of Rural Ghana, London, 1960; and L. P. Mair, "Witchcraft as a Problem in the Study of Religion," in: Cahiers d'études africaines, Vol. 5, Paris, 1964; and Witchcraft, Verona, 1969.

30 An old woman in the sample told me, for instance, that she did not dare ask her children for financial support, lest she be accused of practicing witchcraft. 
The dependence on the extended family at the same time offered a type of security, which is now disappearing. The woman is increasingly forced to rely on herself. New dependencies and insecurities arise: the education of the children becomes a considerable burden without the support of the extended family and lineage; conflicts and difficulties arise when new requirements are confronted with old ideas - for instance, when there are differences of opinion concerning the value of modern education; the position of old women has changed for the worse, since they can no longer automatically depend on the support of their children.

Despite these difficulties, however, the analysis showed, that the changes brought about through progressive urbanization, gradual industrialization and through the positive effects that have resulted from the efforts of the independent Ghanaian government assisted, especially in the educational sector, by the Christian missions, have brought about advancements in all areas of social life.

To be sure, Ghana is confronted with the problem that industrialization and general economic development have not kept pace with the educational expansion. As a result, many of the educated, especially at the middle school level, cannot find appropriate employment. These difficulties also have their effect on the occupational opportunities for girls, so that an increasing equality of chances for women in the educational sector does not, because of the scarcity of vacancies, give her a factual equality of occupational chances. However, in the short period since women have systematically been encouraged to make use of all opportunities, they have placed representatives in nearly all professions. By the time of the 1960 Census women were represented among physicians, lawyers, librarians, chemists, pharmacists, or government administrators and executive officers. Certainly, the numbers are as yet extremely small, but the fact that they increase in the younger age groups may indicate, that future developments will show a significant expansion of professional opportunities for women.

As far as political participation is concerned, it can also be said, that practical political engagement increases, where the younger age groups among the women are concerned. If this trend continues, then it may be expected, that once the women are sufficiently educated and no longer primarily tied down to their positions as housewives, they will increasingly participate in the economic and political life of the nation. 


\section{Data on Indonesian Foreign Policy}

\section{By Helmut Heinzlmeir}

The abortive putsch of Sept. 30/Oct. 1, 1965, not only brought about far-reaching shifts of power in domestic policy but also led to an evident change in foreign policy.

Before investigating this change and prior to appraising the present position of Indonesia within the international system Indonesia's foreign policy shall be set forth in its proper order in a short historical review since 1945.

Obvious criteria of the change that happened after 1965 were the end of the confrontation against Malaysia, the breaking of Indonesia's relations with China, the forsaking of the universal policy as carried by the "New Emerging Forces", the re-entering into the UNO, and the re-approach toward the United States. In close collaboration with the International Monetary Fund and the industrial countries of the West Indonesia's economy has undergone deep-reaching reforms.

The West alone - the USA and Japan in particular - have in the time following been willing to place substantial economic help at the disposal of the new anticommunist government in Djakarta. Thus, Washington and Tokyo became the most important points of reference of Djakarta which is following this development with some ambivalence. To the United States which, if occasion arises, may withdraw from the Asiatic continent Indonesia is gaining increasingly in importance. The ambition of Djakarta as to regional policy - it sees its sphere of influence in Southeast Asia - is to a growing extent being superimposed by Tokyo's overwhelming economic ascendancy.

\section{The Social Position of Women in Ghana}

\section{By Agnes Klingshirn}

In traditional society the woman had, within certain defined limits, a secure place with unequivocal rights and duties. In the same measure as she begins to attain economical independence and tries to emancipate herself, she finds herself in a situation where she loses the security, which the traditional family system, which is in a process of disintegration, offered her. The numerous voluntary associations, especially the mutual aid and benevolent thrift societies, in which the women predominate 10 to 1 , are an expression of this precarious situation. They demonstrate at the same time the greater economic and social insecurity of the women and their drive to change the situation in their favor.

The study shows, however, that despite these enormous difficulties there are a number of factors which contribute to the gradual enhancement of the status of women in all major areas of life. Progressive urbanization and industrialization, opening up new job opportunities, efforts on the part of the independent Ghanaian government to provide equal opportunities for men and women in the educational as well as the occupational sector and the willingness on the part of the women, especially the educated ones, to make use of these opportunities give ground for the hope that the women will soon take their place beside the men in an effort to establish a new and rational society. 